\title{
GEOMORPHOLOGICAL RISKS, SUBURBANISATION AND NEOLIBERALISATION OF THE URBAN SPACE IN POST-WAR SARAJEVO
}

DOI: http://dx.doi.org/10.18509/GBP.2015.47

UDC: 551.4.04:911.375(497.6)

\author{
Mr. Jordi Martín-Díaz ${ }^{1}$ \\ Dr. Jordi Nofre ${ }^{2}$ \\ Dr. Marc Oliva ${ }^{3}$ \\ Mr. Pedro Palma ${ }^{3}$ \\ ${ }^{1}$ University of Barcelona, Spain \\ ${ }^{2}$ University New Lisbon, Portugal \\ ${ }^{3}$ University of Lisbon, Portugal
}

\begin{abstract}
In May-2014 an intense rainfall event associated with a deep low-pressure system called Tamara caused severe flooding and thousands of landslides in the Western Balkans region, impacting also the city of Sarajevo (Bosnia and Herzegovina). The hydrological and geomorphological hazards to which a significant number of urban and suburban areas built in the Bosnian capital since the end of the war were shown in this episode. This paper focuses on the geomorphological constraints and increased hazards resulted from the new constructions produced after the conflict. Observational and ethnographic fieldwork was conducted between 2010 and 2013, subsequently complemented with the operational support of GIS. It is argued that despite the consensus achieved for developing Sarajevo through strategies aligned with European regulations for sustainability, the city has moved into an increasing unsustainable direction as a result of the need to deal with vulnerable population groups and the international policies that tend to promote a neoliberal urban development.
\end{abstract}

KEYWORDS: Sarajevo, geomorphological risks, floods, suburbanisation, liberalisation urban space.

\section{INTRODUCTION}

The process of globalization has involved significant changes in the model of urbanization in Central and Eastern Europe (CEE) over the last decades. Within the transition framework from the socialist model of urbanization to other forms of spatial development specific urban structures inherited from the socialist regime have been reshaped under neoliberal forms of urban planning and development. The state ownership of the means of production and the absence of a formal real estate market generated urban forms with higher compactness and more presence of green areas in CEE's cities than in Western European cities. In this sense, socialist urban forms were generally more environmentally friendly and sustainable than capitalist urban forms (Hirt and Stanilov 2009).

In the case of Sarajevo, the capital of Bosnia and Herzegovina (BiH), major urban processes which occurred since the end of the Bosnian War (1992-1995) have favoured an expansion of the urban and suburban sprawl. Although this process took place as a 
consequence of the demographic pressure in the immediate years following the war, new urban spaces were later developed as a result of the neoliberal urban policies enacted by the international actors. In this context, the urban development of Sarajevo after the war had a massive challenge of adopting environmental agendas in harsh political and social conditions, such as the accommodation of refugees and internally displaced persons (IDP's), while strongly conditioned by the rugged geomorphological setting of the city. Our objective is to analyse the implementation of Sarajevo's environmental agenda in a harsh social, ethnic and political environment of the post-war period. We argue that despite the consensus of developing Sarajevo through aligned strategies with the European regulations for sustainability, the built environment of the city has moved into an increasing unsustainable direction as a result of the need of dealing with vulnerable groups of population and, on the other hand, the neoliberal policies favouring the urban sprawl. Firstly, we analyse the existing particular geomorphological constraints in Sarajevo for the development of a sustainable built environment. Subsequently, we explore the environmental visions of the Strategic Plan elaborated in line with the European provisions in order to foster the transition from socialism to capitalism. Later, the paper analyses the main urban spatial changes occurred after the conflict, examining the consequent increase of the geomorphological risks in the built environment of the city.

\section{METHODOLOGY}

A first in-depth fieldwork campaign carried out between April and July 2010 aimed at identifying the geomorophological risks of the new urban constructions developed during the post-war period in the area of Sarajevo. Both suburbanization and densification processes were identified and examined according to their geomorphological vulnerabilities. Areas potentially vulnerable to floods and other mass wasting processes widely understood as the downslope displacement of soils, sediments or rocks by a wide range of processes under the influence of gravity - were mapped building a GIS-based model. The second phase of our field research was conducted between July and December 2013 with the purpose of analyzing the urban development policies adopted in Sarajevo after the war. It was focused on the adoption of both new planning tools by local institutions and the role of the international actors in the implementation of the liberal peace building agenda, conducting a total of 23 semi-structured interviews with technicians and managers of the main local and regional institutions working on urban planning and development.

\section{THE GEOMORPHOLOGICAL CONSTRAINTS IN THE SARAJEVO AREA}

Sarajevo, located at $518 \mathrm{~m}$ a.s.l., is surrounded by the Dinaric Alps, with elevations exceeding 2,000 m nearby (Treskavica, 2,088 m; Bjelašnica, 2,067 m). This mountain range is formed by Secondary and Tertiary sedimentary rocks, mostly limestones and dolomites. Sarajevo is placed in a depression drained by Miljacka River running ENEWSW. The source of the Miljacka River is located in a karst environment (Kadin Selo region), and down-valleys this river drains the runoff of the mountains surrounding Sarajevo. As in other rivers with Mediterranean climate influence, the maximum discharge of this river takes place between October and December. Furthermore, in only $15 \mathrm{~km}$ it drops more than 1,000 $\mathrm{m}$ in altitude (7.3\% of slope gradient), which enhances erosion activity up-valleys and mass wasting processes, together with the risk of flash floods in the Sarajevo area. The local climate is characterized by the influence of mid 
European continental climate and the maritime influence of the Adriatic Sea. The condensation of the air flowing from the Adriatic when surpassing the coastal mountain ranges determines precipitations of almost $900 \mathrm{~mm}$ per year, mostly concentrated in spring and autumn. The rough local topography can trigger intense rainfall events during these seasons, which may produce severe impacts on settlements and infrastructures.

Sarajevo is distributed in a sedimentary catchment at elevations of 500-600 m, with limestone massifs reaching 1,000-1,500 m encircling the city. The Miljacka and Bosna River drain the hydrographic basin of Sarajevo-Zenica, which was opened during the Tertiary period due to the regional tectonic forces (Hrvatović 2005). The infill of Sarajevo plain is constituted by Quaternary sediments overlying the basal rocks of the Miocene age. As in other extensive parts of the Balkan region, the regional setting is characterized by the widespread distribution of karst landforms. The contact between carbonaceous materials (such as limestone) and water (both from rainfall, runoff or groundwater) initiates the process of dissolution of the original bedrock (Jennings 1985). In the region of Sarajevo the karstification processes are very intense and have originated a wide range of karst morphologies. Sarajevo's basin is flanked by a series of stepped ridges organized following the faults system (Hrvatović 2005). The depressions closed by these mountain steps constitute areas with internal drainage systems known in karst environments as poljes (see Figure 1) with dimensions ranging from decametric to kilometric size.

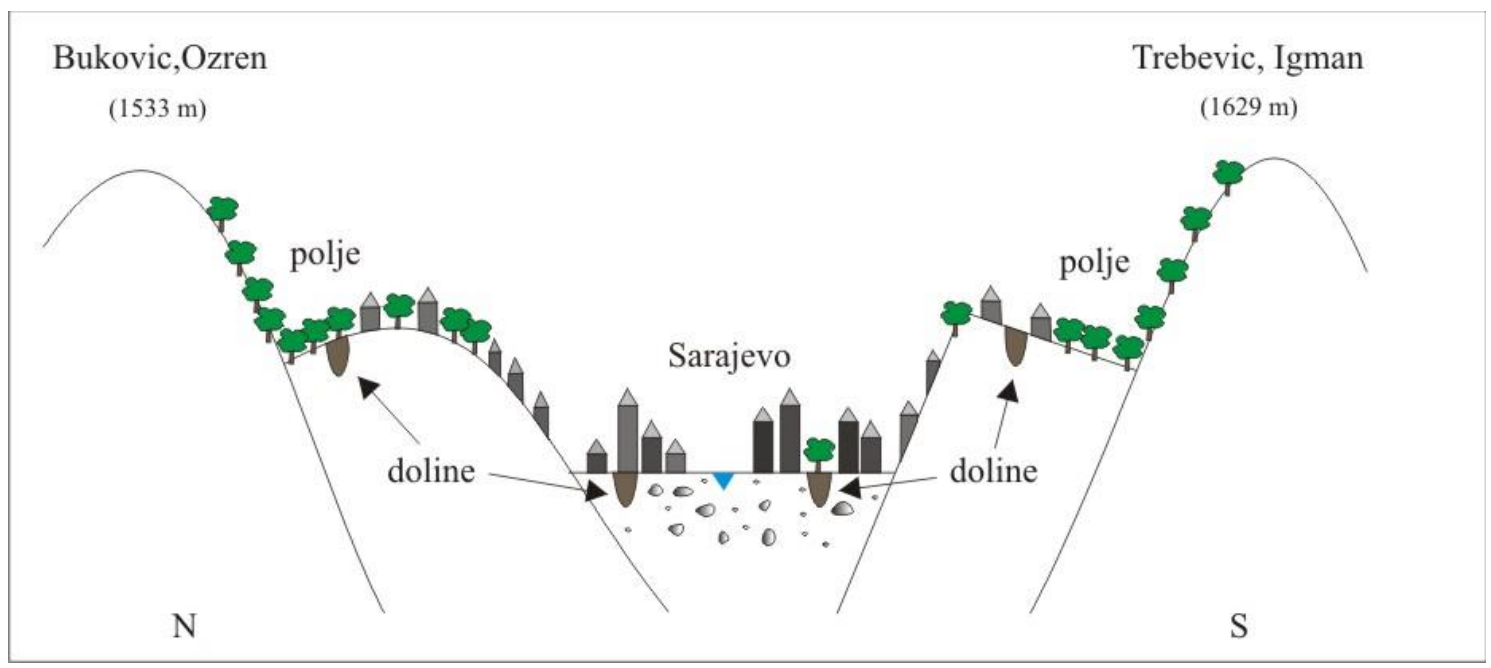

Figure 1. Geomorphological sketch of the regional setting in Sarajevo.

The Miljacka flows following the main faults in the area before streaming into Bosna river. After crossing a steep calcareous gorge in the eastern limit of Sarajevo, the river turns suddenly to the left meandering when entering the city, where it gradually opens forming an elongated alluvial plain parallel to the bed of the river. The contact between the basin and the surrounding relief is pronounced, especially on the left bank of Miljacka, where the escarpment is steeper. By contrast, the slopes in the right side are gentler. However, the present-day distribution of the urban settlements is widespread in both slopes. Doubtlessly, lithology and mountainous terrain condition the geomorphological setting, which in turn have profound implications in the distribution of the population along the Miljacka valley.

The expansion of the city and the higher frequency and larger magnitude of the floods along the XVIII century in the Balkan region (Xoplaki et al. 2001) conditioned the channelling of the Miljacka River in times of the Austrian-Hungarian administration to 
mitigate the damage caused by some floods. Precisely, major floods occurred in mid-May 2014 causing severe damages to equipment, infrastructures and housing (FENA 2014). The impact of the floods was larger in the western outskirts of the city where tributaries Miljacka and Zeljeznica converge with river Bosna. Sarajevo was not the only city affected by this extreme rainfall event, since urban and rural areas in northern Bosnia were the most damaged. For the whole country up to 3,000 landslides were quantified between the $14^{\text {th }}$ and $16^{\text {th }}$ of May, several of them occurred in the Sarajevo area, 27 people perished and 100,000 buildings were destroyed or damaged (Agencies 2014).

\section{BUILDING THE POST-SOCIALIST SARAJEVO, ENVISIONING A SUSTAINABLE CITY}

In post-socialist cities the approval of strategic plans implied the adoption of forms of governance that included the involvement of stakeholders and a broader constituency in the definition of future visions (Tsenkova 2007). In Sarajevo the elaboration of the "Sarajevo Canton Development Strategy until the Year 2015" followed the characteristic combination of strategic long-term visions with short-term actions of strategic plans, defining the future development of Sarajevo until the year 2015. The main goals were the creation of a European metropolis, a profitable business environment and a pleasant living environment (KS 2000). These visions were explicitly developed in fourteen points, in which environmental considerations remarked the specific purpose of making "a city of pleasant living, a clean city, a healthy city, a green city and an ecologically revitalized city" (KS 2000,7). The other pillar of the strategy was the creation of a profitable business environment. Based on private ownership and a successful economy, the privatization of public assets and the creation of a real estate market were central in the post-war and postsocialist urban development of the city (KS 2000).

However, the transferring of planning models among countries without considering local circumstances restricted their impacts. The Development strategy was actually not embedded in the planning legislation and the actualization of the Urban Plan was limited. The revision dealt with the administrative changes of the city, narrowed as consequence of the integration of the mainly rural eastern and southern municipalities into the Republika Srpska (RS) ${ }^{39}$, while including some of the visions of the strategic plan, such as the creation of a real estate market, the possibility to construct temples or the development of new cemeteries. Notwithstanding the backbone of the Urban Plan was not modified and links between environmental visions and goals at the Development Strategy were not developed within the mandatory plan existing until 2015.

\section{RISING THE ENVIRONEMNTAL RISKS OF THE BUILT ENVIRONMENT}

The elaboration of an environmentally sustainable strategy of urban development was soon challenged by the post-war urban processes. Once the OHR was empowered in December 1997 to invigorate the Peace Agreement, it quickly focused on Sarajevo with the objective to rebuild a multi-ethnic capital of $\mathrm{BiH}^{40}$. The Sarajevo Declaration signed in February 1998 set a comprehensive approach aimed at promoting returns and making

\footnotetext{
${ }^{39} \mathrm{RS}$, mainly populated by Bosnian Serbs, is one of the two entities in which Bosnia was divided at the DPA. The Federation of Bosnia and Herzegovina (FBiH) is inhabited mainly by Bosnian Muslims and Bosnian Croats.

40This policy contrasted with the passivity of the international actors in the political and military field during the episodes of ethnic cleansing carried out during the war.
} 
them sustainable. The subsequent removal of the discriminative housing legislation favoured the mass return of refugees and IDP's. Yet pushing for housing repossession implied the eviction of those IDP's who had been sheltered in Sarajevo during the war. Thus, the reluctance of many of them to return to areas controlled by other ethnic groups which were either Serbs or Croats triggered the wave of illegal construction of housing in late 90's, mainly built at the roofs of existing buildings or as new single detached dwellings in the suburbs.

In a context in which ethno-national parties aimed at consolidating ethnic territorialisation after the war (Toal and Dahlman 2006) the OHR supervised land allocations during the period 1999-2003. This involvement was the response to the strategy of some municipalities in Bosnia that were distributing socially owned land to displaced persons from their own ethnic group, which jeopardized the policies of the international organizations to foster minority returns and rebuilding a multi-ethnic society. In May 2003, the OHR enacted a harmonized Law on Construction Land in both entities, the $\mathrm{FBiH}$ and the RS. The new law was a significant step in the efforts of international actors to create a real estate market.

The convergence of the land privatization with the increase of investments, resulting from the continuous push for economic liberalization of the international actors, produced the major wave of real-estate in the city after the war. A good example of this pattern is observed in the office buildings and commercial property projects mainly built since 2005 in the Central Business District - in the Marijin Dvor area - and along the Bulevar Mese Selimovica. New urban developments, some of them also illegally constructed, have played a central role in the urban restructuring and the spatial reorganization of Sarajevo (Martin-Diaz 2014). This process of densification occurred especially in those neighbourhoods emerged during the socialist expansion of the city, breaking a sustainable feature of the urbanism predominant under the socialist rule. These new major urban projects have resulted in an increased waterproofing of the Miljacka River's alluvial plain and the occupation of its most floodable areas (Figure 2).

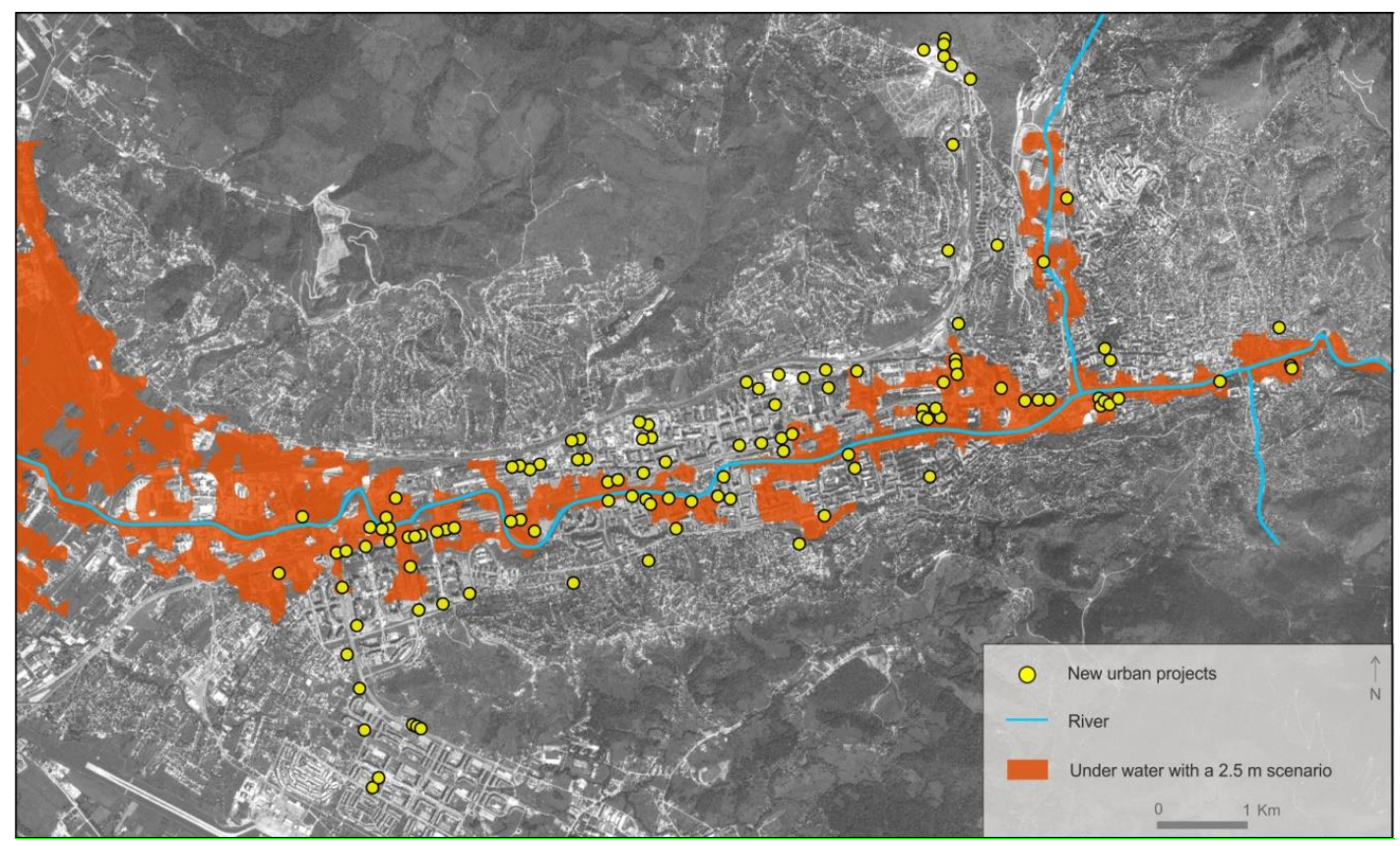

Figure 2. The post-war urban projects and potential floodable areas in a $2.5 \mathrm{~m}$. scenario, the level reached by the Miljacka River in mid-May 2014. 
A major discrepancy between planning rhetoric and practice regarding environmentalfriendly visions in the urban development of Sarajevo soared among local authorities also because of the complexity of processes like the management of the refugee crisis, with about half of the 4.4 million of Bosnians either internally displaced or refugee. The Development Planning Institute anticipated the wave of returns and expected subsequent urban sprawl by modifying the regulation regime, which managed the urban development, into the neighbourhoods with higher slope gradients. The decision showed the desire of local authorities to plan comprehensively the urban sprawl foreseen in the city after the war as pointed in the interviews conducted with technicians from the Development Planning Institute of the Sarajevo Canton. It was the response to the significant demographic pressure performed by IDP's resettled temporary in Sarajevo from areas cleansed ethnically during the war, like the Drina Valley, as well as the refugees and IDP's from Sarajevo willing to get back their pre-war properties. Estimations from the Development Planning Institute suggest that illegal constructions completed during the post-war period totalised between 25,000 and 50,000 units in the area of Sarajevo $^{41}$. These new dwellings were often built in risky sites with steep slopes, like in the neighborhoods of Pofalici, Aneks or Vraca. If illegal constructions were inherited from the socialist period due to the existing housing shortage, it soared after the war in these areas with moderate or high landslide risks (Figure 3) but with a very different meaning and nature since most of the new single family dwellings were consequence of formerly forced displacements (Čengić 2011).

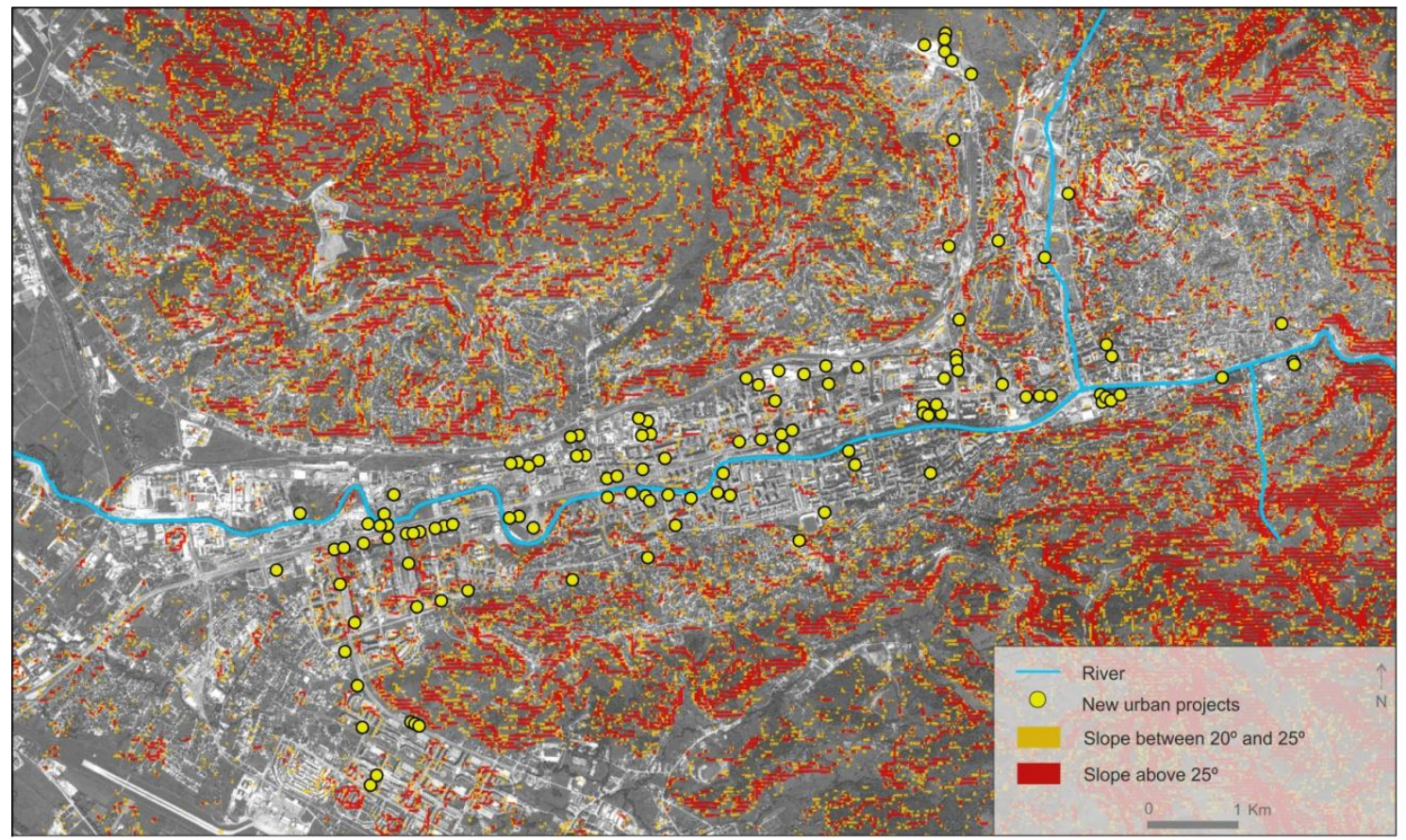

Figure 3. Areas with slope gradients above $20^{\circ}$ with the distribution of the new post-war urban projects. See Martín-Díaz $(2014,311-2)$ for further information about post-war urban projects.

41Official data will not be available until the data release of the first Census celebrated in October 2013, the first since the independence of $\mathrm{BiH}$ in 1992. 


\section{CONCLUSIONS AND PERSPECTIVES}

The major floods occurred in May 2014 in $\mathrm{BiH}$, with large devastating effects in many urban areas including Sarajevo, have shown evidence of the geomorphological risks to which many of these built environments are exposed. The geomorphological context of the central areas of Sarajevo in the Miljacka valley has historically conditioned the urban development of the city.

The high demographic pressure over Sarajevo in the years following the Bosnian war (1992-1995) added another layer of complexity in the urban development management. Anticipating a potential massive return of the refugees and IDP's to the city, the Development Planning Institute programmed new tools in order to regulate the urban growth in the slopes. The approval of regulation plans aimed at providing basic services and a safety environment for people in precarious situations after the conflict, but moved into the higher gradient areas of the city the urban sprawl which was triggered after the housing repossession.

Furthermore, policies enacted by international actors had significant environmental implications moving the built environment in Sarajevo further into a long-term unsustainable direction. Land liberalization policies culminated with the Law on Construction Land in 2003 which led to an urban densification in central Sarajevo with enhanced urban sprawl in the surroundings. The recent extreme rainfall events confirm such unsustainable path in some highly-densified urban areas as well as in new suburban neighbourhoods located in steep slopes and floodable areas.

Hence, along with the poor translation of the environmental visions into the rest of the planning hierarchy, both the creation of a real estate market and the post-war demographic pressure have been continuously undermining the very foundations of the sustainable development agenda in the city of Sarajevo, as shown in the evolution of the built environment. In vulnerable geomorphological urban settlements the elaboration and implementation of a comprehensive sustainable strategy of urban development must be seen as a priority even though dealing with complex social and urban processes. In this sense, the proximity of the ending of the Sarajevo Canton Development Strategy and the Urban Plan in 2015 is an opportunity to rethink a more balanced social and environmental sustainable strategy, taking into account not only the particular geomorphological setting of the city of Sarajevo, but also its political, socio-economic and symbolic specificities. 


\section{REFERENCES}

[1] Agencies 2014 Death toll rises to 43 in Serbia and Bosnia floods The Telegraph 18 May 2014

[2] Eleni Xoplaki, Panagiotis Maheras \& Juerg Luterbacher. Variability of climate in meridional Balkans during the periods $1675-1715$ and 1780-1830 and its impact on human life Climatic Change, vol. 48, pp 581-615, 2001

[3] Federalna Novinska Agencija (FENA) 2014 Obrušilo se korito Miljacke kod mosta Ćumurija, 15 May 2014

[4] Gerard Toal \& Carl Dahlman. The "West Bank of the Drina": Land Allocation and Ethnic Engineering in Republika Srpska Transactions Institute of British Geographers, vol. 31, pp 304-322, 2006.

[5] Hazim Hrvatović. Geological guidebook through Bosnia and Herzegovina Geological Survey of Bosnia and Herzegovina, Sarajevo 156, 2005

[6] J.N. Jennings. Karst Geomorphology Basil Blackwell, Oxford, 1985

[7] Jordi Martin-Diaz. Urban restructuring in post-war contexts: the Sarajevo case Hungarian Geographical Bulletin, Hungarian Geographical Bulletin, vol. 63, pp 303-317, 2014.

[8] Kanton Sarajevo (KS) Sarajevo Development Strategy until the year 2015 Ministry of reconstruction, development and environmental protection, Sarajevo, 2000

[9] Nihad Čengić. Remodelling urban meaning - the Sarajevo case $4^{\text {th }}$ International Conference on Harzards and Modern Heritage (CICOP), Sarajevo, 2011

[10] Sasha Tsenkova. Urban futures: Strategic planning in post-socialist Europe in Kiril Stanilov ed The Post-Socialist City. Urban Form and Space Transformations in Central and Eastern Europe after Socialism Springer, Dordrecht, pp 447-472, 2007

[11] Sonia Hirt \& Kiril Stanilov. wenty years of transition: the evolution of urban planning in Eastern Europe and the former Soviet Union: 1989-2009 UN Habitat, Nairobi, 2009 